\title{
Sustainability, growth and entrepreneurial orientation of small innovative enterprises
}

\author{
Lyubov Lipych*, Oksana Kbilukha*, Myroslava Kushnir ${ }^{* * *}$, \\ Iryna Volynets ${ }^{* * *}$, Liudmyla Shostak ${ }^{* * * * *}$
}

Received: 2021-06-16

Accepted: 2021-08-14

DOI: http:// doi.org/10.46489/lbsh.2021-1-2-3

Abstract. Almost all over the world, small business is a source of prosperity and sustainability for societies and nations. Therefore, research on small businesses in measuring sustainability is essential for achieving several sustainable development goals. In this article, we propose to reflect on the relationship between entrepreneurial orientation, growth and sustainability of a small business. This study consists of three main parts. Firstly, we revealed the role of small businesses in Ukraine's sustainable development and explored the European experience. Secondly, we explored the main components of business orientation and enterprise growth of Ukrainian small innovative enterprises. Thirdly, we established the relationship between the individual components of enterprise growth and its entrepreneurial orientation. We also discussed the informatization issues in connection with expanding the entrepreneurial orientation of small enterprises to strengthen their role in sustainable development processes, especially in the context of the COVID-19 pandemia. This research can be helpful both to SMEs and the government as the basis for developing and changing policies on small business growth and innovations.

Keywords: small enterprises, innovative enterprises, entrepreneurial orientation, enterprise growth, sustainable development goals

\footnotetext{
${ }^{*}$ Lyubov Lipych, DSc (Economics), Professor, Department of Entrepreneurship, Trade and Logistics, Lutsk National Technical University, Lvivska 75, 43018 Lutsk, Ukraine, e-mail: lglipych@gmail.com (corresponding author), ORCID: https://orcid.org/0000-0002-9059-7271

** Oksana Khilukha, PhD, Associate Professor, Department of Enterprise Economics and Information Technology, Lviv University of Business and Law, Kulparkivska str. 99, 79021 Lviv, Ukraine, ORCID: https://orcid.org/0000-0002-1228$\underline{7171}$

${ }^{* * *}$ Myroslava Kushnir, PhD, Art. teacher, Department of Applied Economics and Business, Ukrainian Catholic University, Ilariona Sventsitskoho 17, 79011 Lviv, Ukraine, ORCID: https://orcid.org/0000-0002-4441-4278

${ }^{* * * *}$ Iryna Volynets, Candidate of Economic Sciences, Associate Professor, Department of Management and Administration, Lesya Ukrainka Volyn National University, Prosp. Voli, 13, 43025 Lutsk, Ukraine, ORCID: https://orcid.org/0000-0003-2556-2109

${ }^{* * * * *}$ Liudmyla Shostak, Candidate of Economic Sciences, Associate Professor, Department of Entrepreneurship and Marketing, Lesya Ukrainka Volyn National University, Prosp. Voli, 13, 43025 Lutsk, Ukraine, ORSID: https://orcid.org/0000-0001-8786-9582
} 


\section{INTRODUCTION}

The main reason for the significant attention of scientists to the small business is that it plays a vital role in shaping the level of employment, ensuring a proper competitive environment for medium-sized businesses and improving the socio-economic development of society as a whole. Small enterprises are increasingly directing their activity to establish innovative products and make creative organizational decisions. The benefits of such activity are usually analyzed through the prism of rising competitiveness, gaining new market positions, using existing business and management competencies and available resources. On the other hand, the success of such activity largely depends on the entrepreneurial behaviour, innovation potential and level of entrepreneurship.

Traditionally, small businesses are the driver of progress and innovation due to greater flexibility and a lower level of bureaucracy. However, high competition and the search for their niche contain stagnation and push small businesses to keep moving. Until recently, the main problem for small businesses was limited funding, but new methods of finding support for startups and innovative ideas have revealed the potential. As a result, new ideas for improving the world are now emerging in small businesses' competition.

Small business is an essential factor in sustainable development. By increasing employment and living standards, providing food, educational services, implementing innovations related to energy efficiency and waste management, small businesses are building a sustainable future for our planet. However, we must remember that altruistic behaviour is challenging in highly competitive circumstances. Therefore, we seek to explore the phenomenon of entrepreneurial orientation on the example of small enterprises in Ukraine and their role in ensuring sustainable development.

The entrepreneurial orientation is a characteristic of the enterprise manifested in strategic decisions aimed at responding quickly to the challenges of a turbulent environment. An entrepreneurial enterprise creates innovations, takes an initial position and takes risky measures. The entrepreneurial orientation intensity feels the influence of various internal (human capital potential, available material values, own research and development, knowledge, et cetera) and external factors caused by the external environment. Therefore, small businesses must use their entrepreneurial orientation to create a sustainable competitive advantage. A small business has a competitive advantage when it is more successful than its current and potential competitors, measured by its growth rate.

Journeault, M., Perron, A., \& Vallières, L. (2021) note that governments worldwide strive to improve small businesses' social and environmental performance, which are considered essential performers of sustainable development goals.

The research was inspired by the authors' observation of problems related to the definition of entrepreneurial orientation in sustainability problems, small business growth in Ukraine and the lack of a holistic approach to solving this issue.

\subsection{Literature review}

Sustainable entrepreneurship is an essential subject of research in the modern era of the dominance of the doctrine of sustainable development. At the same time, this area is challenging to research because it is multidisciplinary, requires extensive knowledge in various fields of economics, business, politics and environmental sciences (Anand, A., Argade, P., Barkemeyer, R., \& Salignac, F., 2021).

Terán-Yépez, E. et al. (2020) proved that from the standpoint of sustainable development, entrepreneurship could not be considered as achieving economic benefits solely. After analyzing more than two hundred scientific articles, scientists have proved that sustainable entrepreneurship is one of the central areas of research in sustainable development theory. At the same time, the entrepreneurs should make concrete efforts to promote sustainable development principles in the entrepreneurial orientation framework. Hummels, H., \& Argyrou, A. (2021) noted that governments and businesses threaten sustainable development because their focus on meeting current needs does not consider the potential consequences for future generations. 
As a result, "many businesses unjustifiably see themselves as such contributing to sustainable development". Journeault, M., Perron, A., \& Vallières, L. (2021) conclude that, despite their best efforts, SMEs are still trying to integrate the principles of sustainable development into their activities in their business practice.

Dhahri, S., Slimani, S., \& Omri, A. (2021) proved that sustainable entrepreneurship is based on entrepreneurs' behaviour and motivation. The researchers used empirical data and explained how entrepreneurial orientation affects the impact of enterprises on the economic, social and environmental aspects of sustainable development.

Thelken, H. N., \& de Jong, G. (2020) explored the process of shaping the intentions of sustainable entrepreneurs and opportunities to generate social, environmental, and economic value. Researchers emphasized the influence of values and entrepreneurial orientation on the process of forming intentions for sustainability.

Entrepreneurial orientation means a coherent set of interrelated activity types and processes, structures, methods, practices and behaviours used by managers. The definition bases on the assertion that enterprises carrying on business tend to be at greater risk than nonprofit entities. Such enterprises are actively seeking business opportunities and focusing on innovative change, especially in conditions of uncertainty. Entrepreneurial orientation characterizes the firm's state in which organizational processes, practices, and procedures create value through internal entrepreneurial activity (Lumpkin, G. T., Dess, G. G., 1996). Entrepreneurial orientation emerged as a theoretical construction in the organizational and managerial literature and immediately became a popular topic in academic journals, textbooks and specialized publications. The entrepreneurial orientation is one of the most studied concepts; however, there are many definitions since its emergence that significantly change the essence of the concept.

Table 1 provides a broader overview of the studied construction definitions.

Table 1

The interpretation of the definitions entrepreneurial orientation and entrepreneurial enterprise

\begin{tabular}{|l|l|}
\hline \multicolumn{1}{|c|}{ Author } & \multicolumn{1}{|c|}{ Definition } \\
\hline $\begin{array}{l}\text { Mintzberg, H., \& } \\
\text { Waters, J. A. (1982) }\end{array}$ & $\begin{array}{l}\text { Strategy development is an active search for new opportunities and a } \\
\text { dramatic shift forward in an entrepreneurial style of action under the } \\
\text { conditions of uncertainty. }\end{array}$ \\
\hline $\begin{array}{l}\text { Khandwalla, P. N. } \\
\text { (1976) }\end{array}$ & $\begin{array}{l}\text { An entrepreneurial style is characterized by energetic, risk, aggressive } \\
\text { decisions taking. }\end{array}$ \\
\hline $\begin{array}{l}\text { Miller, D., \& Friesen, } \\
\text { P. H. (1982) }\end{array}$ & $\begin{array}{l}\text { The entrepreneurial model is used by enterprises being innovated regularly } \\
\text { and vigorously while taking on significant risk in product and market } \\
\text { strategies }\end{array}$ \\
\hline Miller, D. (1983) & $\begin{array}{l}\text { Entrepreneurial orientation is inherent in an organization that carries out } \\
\text { innovative, risky activities, seeks to be one step ahead of competitors. }\end{array}$ \\
\hline $\begin{array}{l}\text { Morris M. H., Webb J. } \\
\text { W., Franklin R. J. } \\
\text { (2011) }\end{array}$ & $\begin{array}{l}\text { An entrepreneurial firm has decision-making norms that cover proactive, } \\
\text { innovative strategies and contain an element of risk. }\end{array}$ \\
\hline $\begin{array}{l}\text { Covin, J. G., Slevin, D. } \\
\text { P. (1989) }\end{array}$ & $\begin{array}{l}\text { Entrepreneurial enterprises are organisations in which top managers use an } \\
\text { entrepreneurial management style manifested through strategic decision- } \\
\text { making and operational management philosophy. On the other hand, non- } \\
\text { entrepreneurial or conservative enterprises are such firms in which the style } \\
\text { of top management is characterized by risk avoidance, lack of innovation } \\
\text { and passivity or reactivity. }\end{array}$ \\
\hline $\begin{array}{l}\text { Russell Merz, G., \& } \\
\text { Sauber, M. H. (1995). }\end{array}$ & $\begin{array}{l}\text { Entrepreneurial orientation is determined by the firm's level of proactivity } \\
\text { (aggression) in product and market units and the intention to be innovative } \\
\text { to create new market proposals. }\end{array}$ \\
\hline
\end{tabular}




\begin{tabular}{|l|l|}
\hline $\begin{array}{l}\text { Dess G. C., Lumpkin } \\
\text { G. T. (2005) }\end{array}$ & $\begin{array}{l}\text { Entrepreneurial orientation refers to the processes, practices and activities of } \\
\text { decision-making that lead to a new result. It is characterized by one or more } \\
\text { components such as propensity to act autonomously, willingness to } \\
\text { innovate, willingness to take risks, aggressive behaviour towards } \\
\text { competitors, and proactive behaviour concerning market opportunities. }\end{array}$ \\
\hline $\begin{array}{l}\text { Zahra, S. A., } \\
\text { Neubaum, D. O., \& }\end{array}$ & $\begin{array}{l}\text { Entrepreneurial orientation is the sum of radical innovations of the } \\
\text { enterprise, active strategic and risky actions aimed at supporting projects } \\
\text { with unknown results. }\end{array}$ \\
\hline $\begin{array}{l}\text { Giraud Voss, Z., Voss, } \\
\text { G. B., \& Moorman, C. } \\
\text { (2005). }\end{array}$ & $\begin{array}{l}\text { The entrepreneurial orientation is an intention of the firm to be involved in } \\
\text { behaviour that reflects risk-taking, innovation, proactivity, autonomy and } \\
\text { competitive aggression leading to changes in the organization or market. }\end{array}$ \\
\hline $\begin{array}{l}\text { Avlonitis, G. J., \& } \\
\text { Salavou, H. E. (2007). }\end{array}$ & $\begin{array}{l}\text { Entrepreneurial orientation is an organizational phenomenon that reflects } \\
\text { the firms' managerial ability to take proactive or aggressive initiatives to } \\
\text { change the competition in their favour. }\end{array}$ \\
\hline $\begin{array}{l}\text { Van Den Broeck, H., } \\
\text { \& Cools, E. (2006). }\end{array}$ & $\begin{array}{l}\text { Entrepreneurial orientation applies to the strategy of top management in } \\
\text { terms of innovation, proactivity and risk appetite. }\end{array}$ \\
\hline $\begin{array}{l}\text { Pearce, J. A., Fritz, D. } \\
\text { A., \& Davis, P. S. } \\
\text { (2010) }\end{array}$ & $\begin{array}{l}\text { Entrepreneurial orientation can be defined as a set of different but } \\
\text { interrelated behaviours that have the characteristics of innovation, } \\
\text { proactivity, competitive aggression, risk appetite and autonomy. }\end{array}$ \\
\hline
\end{tabular}

\subsection{Theoretical aspects of entrepreneurial orientation}

There are two main approaches to the conceptualization of the concept of "entrepreneurial orientation". The first is a unidimensional approach presented by $D$. Miller (1983) and later supplemented by J. G. Covin and D. P. Slevin (1990). The second is multidimensional, associated with G. T. Lumpkin and D. D. Dess (2005). In the first approach, the critical factors of entrepreneurial orientation are risk-taking, innovation and proactivity. The main idea of this approach is to have all three dimensions simultaneously contribute to the formation of entrepreneurial orientation equally. The elements must interact with each other, and to increase entrepreneurial orientation, managers need to raise the intensity of behaviour and activities in all dimensions.

Consider each of these elements in terms of behavioural characteristics of the enterprise. Innovation characterizes the propensity of the enterprise to experiment, create new ideas, and participate in activities to create new products, processes, and services and openness of organizational culture to new ideas and combinations (Lumpkin, G. T., Dess, G. G., 1996). In other words, innovation determines the readiness and desire of the enterprise to participate in new ventures. Technological, product and administrative innovations are usually considered in the literature (Dess G. C., Lumpkin G. T., 2005).

Another factor is proactivity, manifested as the ability to anticipate future needs and make the necessary changes ahead of competitors (Dess G. C., Lumpkin G. T., 2005). Proactive enterprise with its initiatives forces competitors to respond to its actions (Covin J. G., Slevin D. P., 1990). Willingness to take risks has always been considered a characteristic feature of entrepreneurs. Such factor refers to decisions related to resource allocation, product selection and markets. Willingness to risk reflects the level of willingness of top management to invest significant resources in projects with a significant level of uncertainty when the result is unknown, and there is a high probability of significant losses (Lumpkin, G. T., Dess, G. G., 1996).

The second multidimensional approach factors do not determine the entrepreneurial orientation but its manifestation. Entrepreneurial orientation is identified as a set of independent characteristics, including risk appetite, innovation, proactivity, competitive aggression, and autonomy in the multidimensional approach. Two additional components are added to the Miller / Covin / Slevin scale, and thus the definition of entrepreneurial orientation is expanded. 
Autonomy is a catalyst for entrepreneurial activity and an independent spirit of freedom necessary to create a new enterprise. Competitive aggression is related to the characteristics of the enterprise, reflects the motivation to achieve through intense competition and improve their competitive position in the market (Lumpkin, G. T., Dess, G. G., 1996; Alexandrova M., 2004).

Despite the popularity of the mentioned approaches in determining business orientation in recent years, there have been studies that demonstrate the need to revise some aspects. For example, G. T. Lumpkin and D. D. Dess (1996) emphasized the need and importance of studying the national context and its impact on entrepreneurial orientation and testing such concepts in other countries.

For our study, we adopted five elements of entrepreneurial orientation, three proposed by D. Miller, such as proactivity, innovation and risk, and two supplemented by G.T. Lumpkin and G.G. Dess, such as autonomy and competitive aggression.

The study of the components of entrepreneurial orientation allows determining the strategic prospects of the enterprise to formulate and implement strategic choices in conditions of uncertainty. Therefore, interest in entrepreneurial orientation is steadily growing, and it is becoming one of the priority areas of entrepreneurship.

The research covers not only the phenomenon itself but also the potential of its components. Based on the literature analysis on this issue, we can conclude that the most significant number of studies in small businesses was devoted to the element of "innovation. Therefore, a broader analysis of other components of entrepreneurial orientation in the context of small business growth is justified.

We formulated the following research questions:

$\mathrm{RQ}_{1}$ : What is the role of small businesses in the sustainable development of Ukraine?

$\mathrm{RQ}_{2}$ : How the entrepreneurial orientation impacts the activities of small enterprises in Ukraine?
$\mathrm{RQ}_{3}$ : Is there a connection between the entrepreneurial orientation and the growth of the enterprise?

\section{METHODS}

To solve out defined research questions in the first stage, we performed theoretical analyses of small businesses' role in the sustainable development of Ukraine and the European experience. We used open data and reviewed scientific sources connected to the issues of SMEs and sustainability.

In the second stage, we conducted exploratory analyses of entrepreneurial orientation and growth of the enterprise using Ukrainian small enterprises data. The second stage was conducted from November 2020 to January 2021 using CATI and CAWI methods to collect data from small innovative enterprises. We considered an innovative enterprise as one that introduced any innovation in the last three years, including the introduction of new or improved products or services, new or improved methods of production or providing services, new or improved management methods. To get the representative sample, we analysed the Statistical Compendium "Activities of Large, Medium, Small and Micro Enterprises in 2018" (State statistical service of Ukraine, 2019). As we found that in the sample in 2018, 339,374 small enterprises were registered in Ukraine. Using applied formula by J. Stechkovsky (Steczkowski, J., 1995), we concluded that representative sample should include at least 783 subjects.

We contact 1,200 enterprises (800 core and 400 reserves) from all regions of Ukraine. The reserve of enterprises was formed to prevent lost data issues (because of the respondents' refusal or obsolete records in the database). We send 1200 questionnaires by e-mail and get 923 responses. Thus, the number of correctly filled questionaries was 795 . Using collected data, we assessed the components of entrepreneurial orientation and growth of the enterprise.

Orientation is a multi-vector phenomenon that requires an appropriate research procedure according to scientific developments on entrepreneurship. Entrepreneurial orientation was determined using five components: proactivity, innovation, autonomy, risk and competitive aggression rated on a 5-point Likert 
scale. Creating the scale, we took into account the recommendations for building measuring scales were. We assessed the reliability and accuracy of the scale using Cronbach's alpha reliability coefficient. The Cronbach's alpha coefficient ranges from 0 to 1 . The reference value is in the range of 0.6-0.94. Values below the reference may indicate, for example, poor interdependence between indicators or an insufficient number of questions; thus, too high values may say about a large number of such indicators. In our case, this ratio was 0.729, which proves the reliability of the research tool. Finally, we calculated the level of entrepreneurial orientation as the arithmetic means of the respondents' answers.

It is important is to determine the level of enterprise growth in the context of assessing the efficiency of the enterprise compared to competitors. This indicator is ambiguous, multi-vector, and at the same time such one that it is difficult to quantify. In studies on this topic, there is no agreement on the unambiguous identification of growth indicators of the enterprise. It is often determined through the growth of sales and employment and the growth of assets, market share, production and profits. The choice of indicators to assess the growth of a small enterprise is a difficult task due to the difficulty of access to financial statements. There is no legal need to publish the latter by small enterprises of Ukraine. Therefore, research often uses subjective assessments of the respondents' enterprise growth components, undoubtedly inaccurate. We also used subjective indicators of enterprise growth such as turnover, employment, profit and productivity in the study. The calculation was made using a 5-point Likert scale. Respondents assessed the components of growth over the last three years (2017-2020) compared to direct competitors on a scale from 1 to 5 where 1 is a significant decrease compared to direct competitors, 2 is a decrease, 3 is difficult to say, 4 is an increase, 5 is a significant magnification. When constructing the scale as in the "entrepreneurial orientation" construction, the scale's design and reliability were evaluated using Cronbach's scale's reliability. The coefficient for this scale was 0.943, which proves the research tool's high reliability and efficient processing of respondents' answers.
In the last stage, we calculated correlations between entrepreneurial orientation factors and the enterprise's growth.

We performed the calculations were using the SPSS program version 17.

\section{RESULTS}

\subsection{The role of small business for sustainable development of Ukraine and the European experience}

Small businesses are one of the main tools for the development of the national economy because they:

- form the basis of small-scale production;

- establish the rate of economic growth, form the structure and quality component of gross domestic product, increase the level of democratization of society;

- contribute to the restructuring of the economy, rapid payback, freedom of market choice;

- provide market saturation with goods and services, implementation of innovations, create additional jobs;

- characterized by high mobility, rational forms of management;

- form a layer of entrepreneurs-owners, which is the basis of the middle class; contribute to the weakening of monopoly and the development of healthy competition in the market (Bilous H. P., 2016).

Small enterprises ensure the development of the country's economic system and bring it closer to consumers. Entrepreneurship can solve such economic problems as creating a competitive environment in the country, attracting private capital and foreign investment, and improving existing production technologies. At the same time, these enterprises play the most crucial role in the state - they provide jobs to the country's citizens, create natural sources of their income, ensure the production of goods for work and services.

As for 2019, according to the official data of the State Statistics Committee, the number of small business entities (both legal entities and individuals) was 87 per 10,000 general populations. For comparison: in Italy, this 
indicator is 92, in Spain - 93, in Austria - 94, in Great Britain - 95, in France - 96, in Germany 97 (OECD, n.d.). The data shows the possibility of further growth of small enterprises in the economy.

In the field of small business in Ukraine, as of January 1, 2017, there were 158.6 thousand enterprises, which provided 9\% of GDP. At the same time, in Ukraine's neighbouring Czech Republic, Slovakia and Hungary, the share of small enterprises in GDP was set at 30-40\% (OECD, n.d.).

The territorial structure of the number of small enterprises by region has uneven distribution. From the total number of small enterprises operating in the country, more than half acts in 7 regions of Ukraine (in particular, Kyiv $(25.1 \%$ of the total number of small enterprises in the country), Dnipropetrovsk (8.4), Kharkiv (7.8\%), Lviv (6.5\%), Odesa (6.2\%), Zaporizhia (5.8\%), Vinnytsia (5.3\%) (State statistical service of Ukraine, 2019).

World practice shows that $12 \%$ of small businesses grow into large companies. Unfortunately, in Ukraine, these are only isolated cases, as the growth of small enterprises is blocked. The average term of existence of small Ukrainian enterprises is very insignificant. The life cycle of small enterprises averaged 3-5 years. From 50 to $80 \%$ of Ukrainian small businesses go bankrupt OECD, 2021).

Even in world practice, under the conditions of a favourable external environment in the first five years of existence, from 30 to $70 \%$ of small enterprises go bankrupt. Thus, in the United States, 65\% of companies with up to 20 employees work in bankruptcy in the first four years of existence, and every fourth company - in the first year (UENI Blog, 2021).

Improving the system of microcredit, investment and providing guarantees is one of the urgent tasks of the state for the development of small businesses. Such measures can be helpful to:

- increase the competitiveness of enterprises;

- withdraw most of them from the shadow sector (almost $70 \%$ of small businesses hide their real profits (Bilous H. P., 2016);
- create more jobs.

Analyzing the six most attractive countries in Europe in terms of investment climate Great Britain, Ireland, the Netherlands, Sweden, Norway and Bulgaria, we can emphasize that they all have a "green corridor" for small business development. Ireland ("Celtic Tiger") is the most favourable country for small business development among other European countries. At the same time, the government is taking all possible measures to encourage the emergence of new enterprises, creating desirable conditions for this (corporate tax rate is only $12.5 \%$ ). Bulgaria has become a hub for entrepreneurs from all over the world with the possibility to open a small business there with all the permits in 18 days. In Norway, small businesses can be started online. The simplified procedure saves time, and the risk of operation for small businesses in this country is minimal. In an expensive country of residence - the UK, starting a new business costs an average of \$81.45 (Smale Th., 2017).

According to a study by The world bank group, the Scandinavian countries rank third in ease of doing business, while the United States is eighth in comparison. However, the latter has highly qualified staff and supports innovation in small businesses best of all. James Wilkinson, CEO of Streaming Tank, emphasizes that "people in New York are open and eager for new ideas and concepts" (Smale Th., 2017).

The importance of small business lies in its significant share in the overall structure of the business. In the Organization for Economic Co-operation and Development (OECD) member countries, more than $95 \%$ of all business is held by small and medium-sized businesses. $60-70 \%$ of the employed population work in small and medium businesses (OECD, 2000).

T.V. Chernychko emphasizes that: "Small enterprises provide flexibility and sustainability of the economic system, bring it closer to the needs of specific consumers, and at the same time - play an important social role, providing jobs and providing a source of income for large segments of the population" (Chernychko T.V., 2010, 152). In our opinion, small businesses do even more because they are flexible enough for risky innovation and paving new economic and social development ways. 


\section{2. Entrepreneurial orientation}

The surveyed business entities were mainly involved in the service sector $(68.93 \%)$, production $(21.64 \%)$ and trade $(9.43 \%)$. The structure of the spatial market was dominated by the domestic market (78.11\%), followed by the regional market $(12.83 \%)$, and the international market with the lowest share $(9.06 \%)$. Mature companies that dominated the study sample have existed in the market for more than ten years. They accounted for
$83.52 \%$ of respondents, and the least were companies operating in the market for up to 3 years, only $16.48 \%$.

Analysis of the components of entrepreneurial orientation showed that of the five factors, the highest score was given to innovation. Almost $82 \%$ of respondents rated it at 4 and 5 . At the same time, the lowest level in the ranking went to autonomy that is only $25.86 \%$ of respondents rated 4 and 5 (Table 2).

Table 2

Factor-by-factor assessment of entrepreneurial orientation of the studied enterprises

\begin{tabular}{|l|c|c|c|c|c|}
\hline \multicolumn{2}{|c|}{ Entrepreneurial Orientation Factors } & \multicolumn{4}{|c|}{ Grades from 1 to $5, \%$} \\
\cline { 2 - 6 } & 1 & 2 & 3 & 4 & 5 \\
\hline $\begin{array}{l}\text { Proactivity - the company systematically monitors the } \\
\text { environment to determine future consumer needs and } \\
\text { forecast future demand conditions. }\end{array}$ & 4.53 & 9.07 & 19.06 & 33.60 & 29.87 \\
\hline $\begin{array}{l}\text { Innovation - the enterprises focuses on the } \\
\text { introduction of new products and processes, technical } \\
\text { or organizational changes and creates a culture loyal } \\
\text { to innovation. }\end{array}$ & 5.47 & 7.20 & 21.73 & 39.73 & 41.73 \\
\hline $\begin{array}{l}\text { Autonomy - managers and employees have the right } \\
\text { to make independent decisions, taking care of the } \\
\text { interests of the enterprise. }\end{array}$ & 16.53 & 33.20 & 30.40 & 18.53 & 7.33 \\
\hline $\begin{array}{l}\text { Risk - the company is willing to take risks by entering } \\
\text { a new unexplored market, invest, make changes, such } \\
\text { as innovation. }\end{array}$ & 7.60 & 19.07 & 52.00 & 14.80 & 12.53 \\
\hline $\begin{array}{l}\text { Competitive aggressiveness - the company } \\
\text { systematically improves its competitive position due } \\
\text { to the high quality of products / services and a wide } \\
\text { range of products, introducing innovations. }\end{array}$ & 4.93 & 11.47 & 28.13 & 46.00 & 15.47 \\
\hline
\end{tabular}

Respondents assessed the size of entrepreneurial orientation, answering questions about the functioning of the surveyed enterprise on a scale from 1 to 5 , where 1 - unequivocally no, 2 - no, 3 - difficult to answer, 4 - yes, 5 - unequivocally yes.

Source: own research

The growth of the enterprise was calculated as the arithmetic mean of the respondents' answers to questions about the indicators included in this unidimensional construction.

A detailed analysis of the components of the "enterprise growth" structure showed that in the case of all analyzed variables, i.e. increase in sales / turnover, employment growth, profit growth and productivity growth, more than $56 \%$ of respondents rated the analyzed indicators as "growth" and "significant growth" compared to competitors (Table 3). 
Table 3

Estimation of a construction "growth of the enterprise" components for the last three 2017-2020 years in comparison with direct competitors

\begin{tabular}{|l|c|c|c|c|c|}
\hline $\begin{array}{c}\text { A construction } \\
\text { "growth of the } \\
\text { enterprise" } \\
\text { components }\end{array}$ & 1 & 2 & 3 & 4 & 5 \\
\cline { 2 - 6 } & \multicolumn{5}{|c|}{ Grades from 1 to 5, \% } \\
\hline $\begin{array}{l}\text { Volume (sales) of } \\
\text { turnover }\end{array}$ & 6,4 & 11,3 & 20.4 & 36,7 & 25,2 \\
\hline $\begin{array}{l}\text { The size of } \\
\text { employment }\end{array}$ & 9,0 & 9,5 & 22.1 & 34,8 & 24,6 \\
\hline The amount of profit & 5,3 & 11,2 & 21,3 & 35,7 & 26,5 \\
\hline Productivity & 8,5 & 9,7 & 25,6 & 33,1 & 23,1 \\
\hline
\end{tabular}

Respondents evaluated the performance of enterprises for the last three years (2017-2020) compared to direct competitors on a scale from 1 to 5 , where 1 - a significant decrease compared to direct competitors, $2-\mathrm{a}$ decrease, 3 - difficult to say, 4 - an increase, 5 - significant increase.

Source: personal studies

As noted above, innovation received the highest score among the components of entrepreneurial orientation. According to the content and scope, the following innovations are distinguished: product (creation of new products consumed in the field of production or consumption), environmental (new products and technologies that reduce environmental pollution, provide cleaning of harmful emissions, waste-free processing of raw materials, waste disposal, improving the sphere of life), technological (new ways of producing old or new products, new information systems), economic (innovations in financial or accounting spheres), social (the process of changing working conditions, cultural, environmental and political aspects, changing lifestyles in general ), management (new methods of work used by the administration: the system of strategic planning, modelling of economic processes, personnel management). Respondents assessed the impact of the above types of innovations on enterprise development on a scale from 1 to 5 , where 1 - invisible, $2-$ insignificant influence, 3 - challenging to say, 4 - yes, affect, 5 - the impact is significant. The analysis of answers showed that the greatest impact on the development of the enterprise has technological (43.8\% of respondents) and product $(33.6 \%$ of respondents) innovations, the least environmental $(7.7 \%$ of respondents) and social $(6.3 \%$ of respondents).

\subsection{Relationships between enterprise growth and entrepreneurial orientation}

In the next stage, we investigated statistically significant relationships between enterprise growth and its entrepreneurial orientation. To assess this dependence, we used Pearson's Correlation Coefficient. We processed data with SPSS and get the following correlation matrix (Table 4).

The obtained results confirmed a statistically significant density of the relationship between the indicators of the analyzed structures.

We confirmed that in Ukraine, entrepreneurial orientation and enterprise growth are also factors that unite the variables identified and described by Avlonitis, G. J., \& Salavou, H. E. (2007), Covin, J. G., Slevin, D. P. (1989), Covin, J. G., Wales, W. J. (2019), Dess G. C., Lumpkin G. T. (2005), Khandwalla, P. N. (1976), Rauch, A., Wiklund, J., Lumpkin, G. T., Frese M. (2009). At the same time, we found a significant correlation (significant at the 0.01 level) between risk and profit, proactivity and productivity. Furthermore, the correlation between innovation and productivity, autonomy, aggression and turnover (significant at the 0.05 level) is also essential. 
Table 4

Correlations between variables on enterprise growth and its entrepreneurial orientation

\begin{tabular}{|c|c|c|c|c|c|c|c|c|c|c|}
\hline & & Proactivity & Innovation & Autonomy & Risk & Aggressiveness & Turnover & Employment & Profit & Productivity \\
\hline Proactivity & $\begin{array}{l}\text { Pearson Correlation } \\
\text { Sig. (2-tailed) } \\
\mathrm{N}\end{array}$ & \begin{tabular}{r|}
1 \\
795 \\
\end{tabular} & & & & & & & & \\
\hline Innovation & $\begin{array}{l}\text { Pearson Correlation } \\
\text { Sig. (2-tailed) } \\
\mathrm{N}\end{array}$ & $\begin{array}{r}.664^{* *} \\
.000 \\
795\end{array}$ & $\begin{array}{r}1 \\
795\end{array}$ & & & & & & & \\
\hline Autonomy & $\begin{array}{l}\text { Pearson Correlation } \\
\text { Sig. (2-tailed) } \\
\mathrm{N}\end{array}$ & $\begin{array}{r}.657^{* *} \\
.000 \\
795\end{array}$ & $\begin{array}{r}.559^{* *} \\
.000 \\
795\end{array}$ & $\begin{array}{r}1 \\
795\end{array}$ & & & & & & \\
\hline Risk & $\begin{array}{l}\text { Pearson Correlation } \\
\text { Sig. (2-tailed) } \\
\mathrm{N}\end{array}$ & $\begin{array}{r}.779^{* *} \\
.000 \\
795\end{array}$ & $\begin{array}{r}.774^{* *} \\
.000 \\
795\end{array}$ & $\begin{array}{r}.654^{* *} \\
.000 \\
795\end{array}$ & \begin{tabular}{r|}
1 \\
795
\end{tabular} & & & & & \\
\hline Aggressiveness & $\begin{array}{l}\text { Pearson Correlation } \\
\text { Sig. (2-tailed) } \\
\mathrm{N}\end{array}$ & $\begin{array}{r}.878^{* *} \\
.000 \\
795\end{array}$ & $\begin{array}{r}.695^{* *} \\
.000 \\
795\end{array}$ & $\begin{array}{r}.576^{* *} \\
.000 \\
795\end{array}$ & $\begin{array}{r}.885^{* *} \\
.000 \\
795\end{array}$ & $\begin{array}{r}1 \\
795\end{array}$ & & & & \\
\hline Turnover & $\begin{array}{l}\text { Pearson Correlation } \\
\text { Sig. (2-tailed) } \\
\text { N }\end{array}$ & \begin{tabular}{r|}
$.432^{*}$ \\
.014 \\
795
\end{tabular} & $\begin{array}{r}.349^{*} \\
.022 \\
795\end{array}$ & $\begin{array}{r}.430^{*} \\
.019 \\
795\end{array}$ & $\begin{array}{r}.294^{*} \\
.021 \\
795\end{array}$ & $\begin{array}{r}.334^{*} \\
.009 \\
795\end{array}$ & $\begin{array}{r}1 \\
795\end{array}$ & & & \\
\hline Employment & $\begin{array}{l}\text { Pearson Correlation } \\
\text { Sig. (2-tailed) } \\
\text { N }\end{array}$ & \begin{tabular}{r|}
$.453^{*}$ \\
.022 \\
795
\end{tabular} & $\begin{array}{l}.140 \\
.065 \\
795\end{array}$ & $\begin{array}{r}.211^{*} \\
.049 \\
795\end{array}$ & $\begin{array}{r}.315^{*} \\
.033 \\
795\end{array}$ & $\begin{array}{l}.119 \\
.094 \\
795\end{array}$ & $\begin{array}{r}.493^{*} \\
.029 \\
795\end{array}$ & $\begin{array}{r}1 \\
795\end{array}$ & & \\
\hline Profit & $\begin{array}{l}\text { Pearson Correlation } \\
\text { Sig. (2-tailed) } \\
\text { N }\end{array}$ & $\begin{array}{r}.398^{*} \\
.013 \\
795\end{array}$ & $\begin{array}{r}.344^{*} \\
.016 \\
795\end{array}$ & $\begin{array}{l}.198 \\
.084 \\
795\end{array}$ & $\begin{array}{r}.473^{* *} \\
.009 \\
795\end{array}$ & $\begin{array}{r}.272^{*} \\
.026 \\
795\end{array}$ & $\begin{array}{r}.762^{* *} \\
.000 \\
795\end{array}$ & $\begin{array}{r}.712^{* *} \\
.000 \\
795\end{array}$ & $\begin{array}{r}1 \\
795\end{array}$ & \\
\hline Productivity & $\begin{array}{l}\text { Pearson Correlation } \\
\text { Sig. (2-tailed) } \\
\text { N }\end{array}$ & $\begin{array}{r}.511^{* *} \\
.000 \\
795\end{array}$ & $\begin{array}{r}.492^{*} \\
.015 \\
795\end{array}$ & $\begin{array}{r}.384^{*} \\
.039 \\
795\end{array}$ & $\begin{array}{r}.212 \\
.076 \\
795\end{array}$ & $\begin{array}{r}.298^{*} \\
.019 \\
795\end{array}$ & $\begin{array}{r}.853^{* *} \\
.000 \\
795 \\
\end{array}$ & $\begin{array}{r}.844^{* *} \\
.000 \\
795\end{array}$ & $\begin{array}{r}.798^{* *} \\
.000 \\
795\end{array}$ & $\begin{array}{r}1 \\
.000 \\
795\end{array}$ \\
\hline
\end{tabular}

*. Correlation is significant at the 0.05 level (2-tailed)

**. Correlation is significant at the 0.01 level (2-tailed) 


\section{DISCUSSION}

Small businesses play an essential role in our country's economy because they are an integral part of its socio-economic system. However, their normal development is possible only in a balanced system of state and legal measures. It is possible to promote the development of small enterprises only by combining different methods of regulation and support, the main of which are: financial and credit support; favourable tax policy; creation of a policy of structural changes, in order to harmonize the domestic economy with the standards of EU member states; optimization and acceleration of Ukraine's integration processes into world structures.

A significant problem is the low level of informatization processes and innovative technologies. Only every 4th enterprise in Ukraine made a gross capital investment, and among small enterprises - every 5th. Out of every 100, only 12-13 enterprises incurred expenses for informatization (and only eight among small enterprises). Only one of 287 enterprises $(0.39 \%$ of the total business entities) incurred expenditures on technological innovations in 2016. For small enterprises, this indicator was one out of 982 (or $0.1 \%$ ) (State statistical service of Ukraine, 2019).

COVID-19 pandemia in the whole world and Ukraine especially shows the fragility of old-style management with its accent on human resources, micro-operations, and search for ways to minimize taxes. Thus, IT as the component of entrepreneurial orientation can be an essential topic for future research on SMEs growth.

\section{CONCLUSIONS}

Highlights of the study are as follows:

- the studied innovative small enterprises are characterized by a strong entrepreneurial orientation of the all analyzed components, which may indicate that the entrepreneurial behaviour of these entities goes beyond existing management models;

\section{References}

Alexandrova M. (2004). Entrepreneurship in transition economy: The impact of environment on entrepreneurial orientation.
- more than half of the surveyed enterprises over the past three years (20172020) recorded an increase in turnover, employment, profits and productivity, which could affect the development of these entities in various areas, including improving quality, introducing new management methods, production modernization;

- entrepreneurial orientation (as the combination of proactivity, innovation, risk, autonomy, competitive aggression) shows notable correlation with enterprise growth (as the combination of turnover, employment, profit and productivity);

- the main directions to improve management of Ukrainian small enterprise growth in connection with entrepreneurial orientation are profit and productivity advancing considering risk and proactivity issues; furthermore, managers should notice the correlation between innovations and productivity, autonomy, aggressiveness and turnover;

- analysis of the innovations types impact on the development of the enterprise showed that the most significant impact has technological innovations, particularly information technology.

Sustainable development of SMEs can be achieved by entrepreneurs themselves, without any government support. We can see many examples on the Ukrainian market, then small enterprises leading by managers with strong entrepreneurial orientation have excellent growth potential and are socially responsible. However, in crisis, SMEs feels undisputable risks and need some help to stay sustained. During pandemia, the Ukrainian government secures SMEs' financial risks, which arose due to quarantine constraints. We believe that this research can be helpful both to SMEs and the government as the basis for developing and changing policies on small business growth and innovations.

Problems and Perspectives in Management, (2), 140-148.

Anand, A., Argade, P., Barkemeyer, R., \& Salignac, F. (2021). Trends and patterns in sustainable entrepreneurship research: A bibliometric review and research agenda. Journal 
of Business Venturing, 36(3), 106092. https://doi.org/10.1016/i.jbusvent.2021.10609 $\underline{2}$

Avlonitis, G. J., \& Salavou, H. E. (2007). Entrepreneurial orientation of SMEs, product innovativeness, and performance. Journal of Business Research, 60(5), 566-575. https://doi.org/10.1016/j.jbusres.2007.01.001

Backhaus, K., Erichson, B., Plinke, W., Schuchard-Ficher, C., Weiber, R. (2016). Multivariate Analysemethoden. Eine anwendungsorientierte Einfübrung. Gabler Verlag. https://doi.org/10.1007/978-3-662-46076-4

Bajdor, P., \& Pawełoszek, I. (2020). Data Mining Approach in Evaluation of Sustainable Entrepreneurship. Procedia Computer Science, 176, 2725-2735.

https://doi.org/10.1016/j.procs.2020.09.284

Bilous H. P. (2016). Development of small business in Ukraine, Ekonomika Ukrainy, 5, 3436.

Chernychko T.V. (2010). Mistse ta znachennia maloho biznesu $\mathrm{v}$ rozvytku natsionalnoi ekonomiky. Naukoryi visnyk NLTU Ukrainy, 20(4), 151-156.

Covin J. G., Slevin D. P. (1990). New venture strategic posture, structure, and performance: An industry life cycle analysis. Journal of Business Venturing, 5 (2), 123-135. https://doi.org/10.1016/0883-9026(90)90004D

Covin, J. G., Slevin, D. P. (1989). Strategic management of small firms in hostile and benign environments. Strategic Management Journal, $\quad 10 \quad$ (1), 75-87. https://doi.org/10.1002/smj.4250100107

Covin, J. G., Wales, W. J. (2019). Crafting High-Impact Entrepreneurial Orientation Research: Some Suggested Guidelines. Entrepreneurship Theory and Practice, 43(1), 318. doi: $10.1177 / 1042258718773181$

Denicolai, S., Zucchella, A., \& Magnani, G. (2021). Internationalization, digitalization, and sustainability: Are SMEs ready? A survey on synergies and substituting effects among growth paths. Technological Forecasting and Social Change, 166, 120650. https://doi.org/10.1016/i.techfore.2021.12065 $\underline{0}$

Dess G. C., Lumpkin G. T. (2005). The role of entrepreneurial orientation in stimulating effective corporate entrepreneurship. The Academy of Management Executive, 19 (1), 147-156. https://doi.org/10.5465/ame.2005.15841975

Dhahri, S., Slimani, S., \& Omri, A. (2021). Behavioral entrepreneurship for achieving the sustainable development goals. Technological Forecasting and Social Change, 165, 120561. https://doi.org/10.1016/j.techfore.2020.12056 $\underline{1}$

Engelen, A., Kube, H., Schmidt, S., Flatten, T. C. (2014). Entrepreneurial Orientation in Turbulent Environments: The Moderating Role of Absorptive Capacity. Department Research Policy, 43, 1353-1369. https://doi.org/10.1016/j.respol.2014.03.002

Field, A. (2009). Discovering Statistics Using SPSS. 3rd Edition, Sage Publications Ltd.

George, B. A., Marino, L. (2011). The epistemology of entrepreneurial orientation: Conceptual formation, modeling, and operationalization. Entrepreneurship Theory and Practice, $\quad 35(5), \quad$ 989-1024. https://doi.org/10.1111\%2Fj.15406520.2011.00455.x

Giraud Voss, Z., Voss, G. B., \& Moorman, C. (2005). An empirical examination of the complex relationships between entrepreneurial orientation and stakeholder support. European Journal of Marketing, 39(9/10), 1132-1150. https://doi.org/10.1108/03090560510610761

Hummels, H., \& Argyrou, A. (2021). Planetary demands: Redefining sustainable development and sustainable entrepreneurship. Journal of Cleaner Production, 278, 123804. https://doi.org/10.1016/j.jclepro.2020.123804

Journeault, M., Perron, A., \& Vallières, L. (2021). The collaborative roles of stakeholders in supporting the adoption of sustainability in SMEs. Journal of Environmental Management, 287, 112349 .

https://doi.org/10.1016/i.jenvman.2021.11234 $\underline{9}$

Kaiser, H. F., \& Rice, J. (1974). Little Jiffy, Mark Iv. Educational and Psychological Measurement, 34(1), 111-117. https://doi.org/10.1177/001316447403400115

Khandwalla, P. N. (1976). The Design of Effective Top Management Style. Vikalpa: The Journal for Decision Makers, 1(2), 41-58. https://doi.org/10.1177/0256090919760203 
Lumpkin, G. T., Dess, G. G. (1996). Clarifying the entrepreneurial orientation construct and linking it to performance. Academy of Management Review, 21 (1), 135-172. https://doi.org/10.2307/258632

Miller, D. (1983). The correlates of entrepreneurship in three types of firms. Management Science, 29 (7), 770-791. https://doi.org/10.1287/mnsc.29.7.770

Miller, D., \& Friesen, P. H. (1982). Innovation in conservative and entrepreneurial firms: Two models of strategic momentum. Strategic Management Journal, 3(1), 1-25. https://doi.org/10.1002/smj.4250030102

Mintzberg, H., \& Waters, J. A. (1982). Tracking Strategy in an Entrepreneurial Firm. Academy of Management Journal, 25(3), 465-499. https://doi.org/10.2307/256075

Morris M. H., Webb J. W., Franklin R. J. (2011). Understanding the manifestation of entrepreneurial orientation in the nonprofit context. Entrepreneurship Theory and Practice, 35 (5), 947-971.

https://doi.org/10.1111\%2Fj.15406520.2011.00453.x

OECD. (2000). Small and Medium-sized Enterprises: Local Strength, Global Reach. Policy Brief. http://www.oecd.org/cfe/leed/1918307.pdf

OECD. (2021). The covid-19 crisis in Ukraine.

https://www.oecd.org/eurasia/competitivenes s-programme/eastern-partners/COVID-19-

CRISIS-IN-UKRAINE.pdf

OECD. (n.d.). Compendium of Enterprise Statistics in Ukraine 2018. https://www.oecd.org/eurasia/competitivenes s-programme/eastern-partners/CompendiumEntreprise-Statistics-Ukraine-2018-EN.pdf

Osborne, J. W., Costello, A. B. (2004). Sample size and subject to item ratio in principal components analysis. Practical Assessment, Research \& Evaluation, 9 (11). https://doi.org/10.7275/ktzq-jq66

Pearce, J. A., Fritz, D. A., \& Davis, P. S. (2010). Entrepreneurial Orientation and the Performance of Religious Congregations as Predicted by Rational Choice Theory. Entrepreneurship Theory and Practice, 34(1), 219-

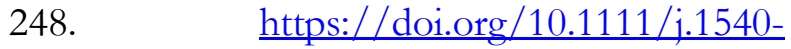
$\underline{6520.2009 .00315 . x}$
Pizzi, S., Corbo, L., \& Caputo, A. (2021). Fintech and SMEs sustainable business models: Reflections and considerations for a circular economy. Journal of Cleaner Production, 281, 125217.

https://doi.org/10.1016/j.jclepro.2020.125217

Rakshit, S., Islam, N., Mondal, S., \& Paul, T. (2021). Mobile apps for SME business sustainability during COVID-19 and onwards. Journal of Business Research, 135, 28-39. https://doi.org/10.1016/i.jbusres.2021.06.005

Rauch, A., Wiklund, J., Lumpkin, G. T., Frese M. (2009). Entrepreneurial Orientation and Business Performance: An Assessment of Past Research and Suggestions for the Future. Entrepreneurship Theory \& Practice, 33 (3), 761787. doi: 10.1111/j.1540-6520.2009.00308.x

Russell Merz, G., \& Sauber, M. H. (1995). Profiles of managerial activities in small firms. Strategic Management Journal, 16(7), 551-564. https://doi.org/10.1002/smj.4250160705

Smale Th. (2017). The Best Countries to Start a Business. https://www.entrepreneur.com/article/287908

Spearman, S. (1904). General intelligence objectively determined and measured. The American Journal of Psychology, 15(2), 201-293. https://doi.org/10.2307/1412107

State statistical service of Ukraine. (2019). Diyal'nist' subyektiv velykoho, seredn'oho, maloho ta mikeropidpryyemnytstva: Statystychnyy zbimyk. http://www.ukrstat.gov.ua/druk/publicat/kat $\underline{\mathrm{u} / 2019 / \mathrm{zb} / 12 / \mathrm{zb} \text { dsp 2018.pdf }}$

Steczkowski, J. (1995). Metoda reprezentacyjna w badaniach zjawisk ekonomiczno-spotecrnych, PWN, Warszawa-Kraków.

Stevens, J. (2002). Applied multivariate statistics for the social sciences. 4th ed. Erlbaum.

Tabachnik, B. G., Fidell, L. S. (2007). Using Multivariate Statistics. 5th ed. Allyn \& Bacon, 966 p.

Terán-Yépez, E., Marín-Carrillo, G. M., Casado-Belmonte, M. del P., \& CapobiancoUriarte, M. de las M. (2020). Sustainable entrepreneurship: Review of its evolution and new trends. Journal of Cleaner Production, 252, 119742.

https://doi.org/10.1016/i.jclepro.2019.119742

Thelken, H. N., \& de Jong, G. (2020). The impact of values and future orientation on intention formation within sustainable 
entrepreneurship. Journal of Cleaner Production, 266, 122052. https://doi.org/10.1016/j.jclepro.2020.122052

UENI Blog. (2021). The best countries in Europe to start a small business. https://blog.ueni.com/news/6-best-countriesin-europe-to-start-a-small-business

Van Den Broeck, H., \& Cools, E. (2006). Searching the heffalump: using traits and cognitive styles to predict entrepreneurial orientation. Vlerick Leuven Gent Working Paper Series. Vlerick Leuven Gent Management School.

Verkhovna Rada Ukrainy. (2010). Pro Natsionalnu prohramu spryiannia rozvytku maloho pidpryiemnytstva $\mathrm{V}$ Ukraini (as amended in 2013). https://zakon.rada.gov.ua/laws/show/215714\#Text

Westman, L., Moores, E., \& Burch, S. L. (2021). Bridging the governance divide: The role of SMEs in urban sustainability interventions. Cities, 108, 102944. https://doi.org/10.1016/j.cities.2020.102944

Zahra, S. A., Neubaum, D. O., \& Huse, M. (2000). Entrepreneurship in Medium-Size Companies: Exploring the Effects of Ownership and Governance Systems. Journal of Management, 26(5), 947-976. https://doi.org/10.1177/014920630002600509 